\title{
Collembola (Arthropoda: Hexapoda) Communities in the Soil of Papaya Or- chards Managed with Conventional and Integrated Production in Espírito Santo, Brazil
}

\author{
Mark Paul Culik', David dos Santos Martins² , José Aires Ventura ${ }^{3}$
}

Biota Neotropica v6 (n3) -http://www.biotaneotropica.org.br/v6n3/en/abstract?short-communication+bn02006032006

\author{
Date Received 06/01/2006 \\ Revised 07/20/2006 \\ Accepted 09/27/2006
}

\author{
Instituto Capixaba de Pesquisa, Assistência Técnica e Extensão Rural - INCAPER \\ Rua Afonso Sarlo 160, CEP 29052-010, Vitória, Espírito Santo, Brasil \\ ${ }^{1}$ Corresponding author: ${ }^{1}$ markculik3@yahoo.com,,${ }^{2}$ davidmartins@ incaper.es.gov.br, ${ }^{3}$ ventura@ incaper.es.gov.br
}

\begin{abstract}
Culik, M.P.; Martins, D.S. and Ventura, J.A. Collembola (Arthropoda: Hexapoda) Communities in the Soil of Papaya Orchards Managed with Conventional and Integrated Production in Espírito Santo, Brazil. Biota Neotrop. Sep/Dec 2006 vol. 6, no. 3 http://www.biotaneotropica.org.br/v6n3/en/abstract?short-communication+bn02006032006 ISSN $1676-0611$
\end{abstract}

Collembola have significant influences on soil microorganisms and fertility but information on these ecologically important arthropods is lacking, especially in agricultural and tropical environments. This research was conducted to identify Collembola species present in the soil of papaya orchards in Espírito Santo, Brazil, and to compare the effect of conventional and integrated production on Collembola in this Neotropical environment. Soil samples $(4.8 \mathrm{~cm}$ diameter, $10 \mathrm{~cm}$ deep) were collected in February, May, August and November 2003, from papaya orchards managed with conventional production (including pesticide application based on little or no pest monitoring or consideration of environmental impact) and integrated production (including selective pesticide application only when necessary based on regular pest monitoring) in one experimental site with three treatments (conventional; integrated with drip irrigation; integrated with microsprinkler irrigation) and four commercial orchards (two with conventional and two with integrated production). Berlese-Tullgren funnels were used to extract Collembola from the soil samples. Averaged over the sampling dates, collembolan densities of the orchards ranged from 14023 to 56001 Collembola per $\mathrm{m}^{2}$. In the experimental site, the species Willemia brevispina, Folsomina cf. onychiurina, Folsomides cf. centralis, Folsomides parvulus, Cyphoderus cf. similis, and Neelus cf. minimus were more abundant with integrated versus conventional production. However, this difference was not apparent in commercial orchards sampled. Results indicate that relatively high populations and diverse communities of Collembola occur in the soil of papaya orchards in Espírito Santo but no collembolan species were found to be consistent biological indicators of conventional or integrated production. The species Acherontiella colotlipana, Willemia brevispina, Brachystomella agrosa, Friesea sublimis, Pseudostachia sp.1, Mesaphorura amazonica, Arlea sp.1, Salina sp.1, and Sphaeridia cf. pumilis are new records for the state of Espírito Santo, and Acherontiella colotlipana and Friesea sublimes, are new records for Brazil.

Key words: Collembola, Carica papaya, biodiversity, Espírito Santo, Brazil

http://www.biotaneotropica.org.br 


\section{Resumo}

Culik, M.P.; Martins, D.S. and Ventura, J.A. Comunidades de Collembola (Arthropoda: Hexapoda) do solo em pomares de mamão com sistemas de produção integrada e convencional no Espírito Santo, Brasil. Biota Neotrop. Sep/Dec 2006 vol. 6, no. 3 http://www.biotaneotropica.org.br/v6n3/en/abstract?short-communication+bn02006032006 ISSN 1676-0611

Este trabalho estudou a influência da Produção Convencional em comparação ao de Produção Integrada, sobre os colêmbolos no Estado do Espírito Santo, com ênfase na identificação das espécies e na determinação da densidade dos colêmbolos no solo. A pesquisa foi feita em pomares de mamão nos municípios de Sooretama (pomares experimentais na Fazenda Experimental de Sooretama, INCAPER) e Linhares (pomares comerciais). Na Fazenda Experimental de Sooretama foram realizadas avaliações em um experimento com os sistemas de produção convencional, e o outro com produção integrada. Foram coletadas quatro amostras de solo de cada tratamento (produção convencional com irrigação por aspersão; produção integrada com irrigação por gotejo; produção integrada com irrigação por microaspersão), nos meses de fevereiro, maio, agosto e novembro de 2003. Em Linhares, foram avaliados dois pomares comercias com sistemas de produção convencional e dois com produção integrada, sendo coletadas três amostras por pomar, da mesma forma e nos meses descritos no experimento de Sooretama. Para a extração dos colêmbolos das amostras de solo foram usados os funis de Berlese-Tullgren. A quantidade média dos colêmbolos nos pomares variou de 14023 a 56001 colêmbolos por m². Nos pomares experimentais em Sooretama algumas espécies foram mais numerosas nos pomares de produção integrada em comparação com o pomar que utilizou o sistema de produção convencional. Esta diferença, no entanto, não foi aparente nos pomares comercias de produção integrada em comparação com os pomares comercias que utilizam o sistema convencional. Os resultados iniciais indicam que as populações de colêmbolos são relativamente elevadas em pomares de mamão no Espírito Santo e com ocorrência de diversas comunidades. São registradas pela primeira vez as ocorrências das espécies Willemia brevispina, Brachystomella agrosa, Pseudostachia sp.1, Mesaphorura amazonica, Arlea sp.1, Salina sp.1, e Sphaeridia cf. pumilis no Estado do Espírito Santo, e Acherontiella colotlipana e Friesea sublimes no Brasil.

Palavras-chave: Collembola, Carica papaya, biodiversidade, Espírito Santo, Brasil 


\section{Introduction}

Collembola are small arthropods (typically less than $2 \mathrm{~mm}$ long), but they are common and abundant, often reaching densities of tens to hundreds of thousands per $\mathrm{m}^{2}$ in the top few centimeters of soils throughout the world, and by feeding on soil microorganisms and dead organic matter these microarthropods have significant influences on soil microbial ecology, nutrient cycling, and fertility (Hopkin 1997, Larink 1997, Zeppelini Filho \& Bellini 2004). However, despite their environmental importance, basic information on the occurrence and ecology of Collembola is lacking (Andre et al. 1994) and the Neotropical collembolan fauna may be among the most diverse but least known in the world (Mari Mutt \& Bellinger 1990). Mari Mutt \& Bellinger (1990, 1996) and Mari Mutt et al. (1996-2001) list approximately 1200 Neotropical collembolan species, of which, despite the known biological diversity of Brazil, only about 200 have been recorded from this country (Culik \& Zeppelini Filho 2003). In contrast, more than 800 Collembola species are known to occur in North America (Christiansen \& Bellinger 1998), 7500 species are known worldwide (Bellinger et al. 1996-2005), and the total number of collembolan species, most undescribed, is estimated to be at least 50000 (Hopkin 2002). Prior to 2000, knowledge of the collembolan species in the Brazilian state of Espírito Santo consisted of records of only ten species (Arle 1939, Arle 1981, Thibaud \& PalaciosVargas 1999) although this area contains some of the most diverse tropical forests in the world (Mori 1989), and recently, the presence of diverse collembolan communities has been confirmed in soils in the region with at least 30 additional collembolan species identified in the state (Potapov \& Culik 2002, Culik et al. 2002).

Just as an understanding of biodiversity depends on actual knowledge of what species occur in specific environments (Straube 2004), a basic first step in understanding the ecology of Collembola in tropical, agricultural, and other environments is knowledge of what species occur in such environments (Stork \& Eggleton 1992). Information on the biology of organisms such as Collembola in agroecosystems is also limited (Crossley et al. 1992) but essential for development of sustainable agricultural systems (Pankhurst et al. 1994).

Therefore, the goal of this research was to address such gaps in basic information on Collembola, to increase knowledge of the collembolan fauna of Espírito Santo, and thus add to knowledge of Neotropical Collembola, and to increase understanding of the biodiversity of Collembola in tropical and agricultural environments in general. Specific objectives of this research were to determine what Collembola species inhabit soils of papaya orchards in Espírito Santo, and to investigate effects of conventional production versus integrated production on Collembola communities in this tropical environment.

\section{Materials and Methods}

This research was conducted at seven papaya orchard sites in northern Espírito Santo, consisting of three experimental orchards located at the Instituto Capixaba de Pesquisa, Assistência Técnica e Extensão Rural (INCAPER) Fazenda Experimental de Sooretama (1903'S; 40 08' W), Sooretama municipality, including one experimental orchard managed conventionally (Sooretama conventional production orchard with overhead irrigation, SO PC) and two experimental orchards managed with integrated practices (Sooretama integrated production orchard with drip irrigation, SO PI-G; and Sooretama integrated production orchard with microsprinkler irrigation, SO PI-M); and four commercial orchards in neighboring Linhares municipality, consisting of two commercial orchards managed conventionally (commercial conventional production orchard NB, NB PC, and commercial conventional production orchard LB, LB PC, $19^{\circ} 27^{\prime} 27 \mathrm{~S} ; 40^{\circ} 06^{\prime} 55 \mathrm{~W}$ ) and two commercial orchards managed with integrated practices (commercial integrated production orchard SV, SV PI, and commercial integrated production orchard CA, CA PI, $19^{\circ} 14^{\prime} 50 \mathrm{~S} ; 40^{\circ} 03^{\prime} 35 \mathrm{~W}$ ).

Conventional production practices in the area of the study included routine use of relatively greater numbers of applications of pesticides of greater toxicity in comparison to integrated production practices which included use of pesticides with reduced toxicity only when necessary based on systematic monitoring of orchard pests (Martins et al. 2003, Tatagiba et al. 2003). The area where the research was conducted has hot, rainy summer and cool, dry winter climatic conditions with maximum temperatures typically ranging from an average of $27^{\circ} \mathrm{C}$ in July to $32^{\circ} \mathrm{C}$ in February and precipitation (1252 $\mathrm{mm}$ per year) ranging from an average of about $40 \mathrm{~mm}$ in June to $200 \mathrm{~mm}$ in December (SIAG 2006).

To sample Collembola of the study sites, soil core samples ( $4.8 \mathrm{~cm}$ diameter) were taken randomly, approximately $1 \mathrm{~m}$ from plants in rows, from the surface $10 \mathrm{~cm}$ of each site at intervals of three months from February 2003 through November 2003. Four and three samples were collected from each of the experimental and commercial sites, respectively, on each sample date. Collembola were extracted from the soil cores using Berlese-Tullgren funnels (18 and 4 $\mathrm{cm}$ diameter top and bottom, respectively; $30 \mathrm{~cm}$ long) with a 25-Watt light bulb mounted in a $24 \mathrm{~cm}$ diameter reflector located above each funnel as a heat source. Soil cores were placed on screens ( $2 \mathrm{~mm}$ mesh) in the funnels approximately $15 \mathrm{~cm}$ below the bulbs. Collection jars $(200 \mathrm{ml})$ with approximately $50 \mathrm{ml} 70 \%$ ethanol plus 5\% glycerin were attached below the funnels and the extraction period was six days. Specimens collected were identified as far as possible to species level and quantified to estimate the collembolan densities of the sites. 
Characteristics of the collembolan communities (density, species richness, diversity, equitability, and dominant species) were determined to evaluate the effects of production systems on collembolan communities. Diversity was measured with the Shannon-Wiener index (H') and dominant species were considered to be species making up $5 \%$ or more of the total number of Collembola collected in each orchard.

\section{Results and Discussion}

Twenty-four species of Collembola were found in this study (Table 1). Of these, nine, Acherontiella colotlipana, Willemia brevispina, Brachystomella agrosa, Friesea sublimis, Pseudostachia sp.1, Mesaphorura amazonica, Arlea sp.1, Salina sp.1, and Sphaeridia cf. pumilis, are new records for the state of Espírito Santo, and two, Acherontiella colotlipana and Friesea sublimes, are new records for Brazil. Several species that could not be identified may be new species (D. Zeppelini, personal communication).

Besides these new biogeographical records, this study is one of only a few that provides information on the species composition of collembolan communities in Brazilian soils (Oliveira \& Deharveng 1995, Culik et al. 2002), which also document the diverse variety of collembolan species present in soils in this country. In the experimental site of the present study, Willemia brevispina, Folsomina cf. onychiurina, Folsomides cf. centralis, Folsomides parvulus, Cyphoderus cf. similis, and Neelus cf. minimus were more abundant with integrated versus conventional production (Table 1). However, this difference was not observed in commercial orchards sampled and no collembolan species were apparent as consistent biological indicators of conventional or integrated production. Likewise, there appeared to be no consistent differences in other community characteristics evaluated that could be related to the different production systems. For example, highest richness and diversity values were observed on sites with integrated production in Sooretama (SO PI-G and SO PI-M) but the other two sites with integrated production that were sampled had among the lowest richness and diversity values (Table 2).

The mean densities of Collembola found in the soil of the papaya orchards in this study, approximately 14000 to 56000 per $\mathrm{m}^{2}$ (Table 2) are higher than those found in soils in other parts of Brazil, which seldom have been found to be more than 20000 per $\mathrm{m}^{2}$ (Adis et al. 1989) and which usually are reported to be less than 10000 per $\mathrm{m}^{2}$ (for example, Adis 2000, Franklin et al. 2001). This difference may be due to differences in methods used to extract Collembola from the soil or perhaps it is due to regional or local variations in collembolan abundance since the densities observed in this study are comparable to those encountered in other agricultural soils in Espírito Santo (Culik et al. 2002). Binsfeld et al. (2004) recently recorded collembolan densities of approximately 30000 per $\mathrm{m}^{2}$ in the soil of a riparian area in Mato Grosso do Sul.

Relatively low Collembola densities (less than 20000 per $\mathrm{m}^{2}$ ) are also commonly found in agricultural soils in temperate (Artemjeva \& Gatilova 1975, Andren \& Lagerlof 1980, Winter et al. 1990, Dittmer \& Schrader 2000) and other tropical environments (Mitra 1993, Badejo \& Van Straalen 1993, Badejo et al. 1995). However, as with tropical soils in general, high Collembola densities (greater than 50000 per $\mathrm{m}^{2}$ ) have also been found in some agricultural soils, in at least some temperate and tropical environments (Andren \& Lagerlof 1983, Heisler \& Kaiser 1995, Axelsen \& Kristensen 2000, Culik et al. 2002). This study provides additional evidence that relatively high Collembola densities may also occur in tropical agricultural soils, in contrast to low densities that might be expected based on suggestions that the abundance of soil fauna is lower in tropical soils than in comparable temperate soils (Salt 1952, Madge 1965, Petersen \& Luxton 1982, Heneghan et al. 1998). It is also notable that in the present study a relatively greater variety of collembolan species were dominant in orchards with integrated production in comparison to the number of dominant species in orchards with conventional production, and four species were dominant only in sites with integrated production (Table 2). This suggests that integrated production may contribute to maintenance of environments favorable for a wider range of Collembola species in comparison to conventional production. Such a potentially positive effect of integrated agricultural production in comparison to conventional production on the biodiversity of Collembola (and perhaps other organisms) in agricultural environments may warrant further study since preservation of biological diversity is likely to be essential to sustainability.

\section{Acknowledgements}

We thank J. Pomorski, D. Skarzynski, Wroclaw University, and D. Zeppelini, Universidade Federal da Paraíba, for help with the collembolan identifications. The Conselho Nacional de Desenvolvimento Científico e Tecnológico CNPq, FINEP, and MAPA, Brazil, provided financial support for this work. 
Table 1. Total number of Collembola in the soil of papaya orchards managed with contrasting conventional production (PC) and integrated production (PI) systems in Espírito Santo in 2003.

\begin{tabular}{|c|c|c|c|c|c|c|c|}
\hline \multirow{2}{*}{ Collembolan Taxa } & \multicolumn{7}{|c|}{ Papaya Orchard } \\
\hline & $\mathrm{SO} \mathrm{PC}^{1}$ & SO PI-G ${ }^{1}$ & SO PI-M ${ }^{1}$ & $\mathrm{LB} \mathrm{PC}^{2}$ & NB PC ${ }^{2}$ & $\mathrm{CA} \mathrm{PI}^{2}$ & $\mathrm{SV} \mathrm{PI}^{2}$ \\
\hline Acherontiella colotlipana & - & - & - & 38 & - & - & 4 \\
\hline Willemia brevispina & 8 & 28 & 72 & - & 9 & - & 6 \\
\hline Xenylla welchi & - & 3 & 1 & 53 & 2 & - & - \\
\hline Hypogastruridae (unidentified) & - & - & - & 4 & 4 & - & - \\
\hline Brachystomella agrosa & - & 1 & 1 & 32 & 1 & - & - \\
\hline Friesea sublimis & - & - & - & 5 & - & - & - \\
\hline Pseudostachia sp.1 & - & - & - & 6 & - & - & - \\
\hline Neanuridae (unidentified) & - & - & - & 1 & 1 & - & - \\
\hline Fissuraphorura cubanica & - & - & - & - & - & 44 & - \\
\hline Mesaphorura amazonica & 150 & 118 & 92 & 178 & 127 & 20 & 255 \\
\hline Arlea sp.1 & - & 34 & 9 & - & 14 & - & 17 \\
\hline Ballistura fitchi & - & - & - & 1 & - & - & - \\
\hline Folsomina cf. onychiurina & 14 & 102 & 120 & 279 & 118 & 497 & 3 \\
\hline Folsomides cf. centralis & - & 2 & 249 & 7 & 1 & 1 & 1 \\
\hline Folsomides parvulus & 26 & 352 & 163 & 230 & 563 & 124 & 3 \\
\hline Isotomiella cf. symmetrimucronata & - & - & - & - & 3 & - & - \\
\hline Isotomurus sp. 1 & - & - & 1 & - & - & - & - \\
\hline Proisotoma tenella & 8 & 16 & 3 & 28 & 4 & - & - \\
\hline Isotomidae (unidentified) & - & 3 & 1 & - & 1 & - & - \\
\hline Pseudosinella cf. biunguiculata & 63 & 125 & 6 & - & 4 & - & - \\
\hline Pseudosinella sp.2 & 67 & 66 & 41 & 6 & 60 & 2 & 5 \\
\hline Seira cf. brasiliana & 3 & 14 & 8 & - & 4 & - & 2 \\
\hline Salina sp.1 & - & 1 & - & - & - & - & - \\
\hline Cyphoderus cf. similis & - & 14 & 14 & 9 & 10 & - & 9 \\
\hline Entomobryoidea (unidentified) & 2 & 1 & - & 1 & - & - & - \\
\hline Neelus cf. minimus & 28 & 111 & 59 & 337 & 11 & 6 & 6 \\
\hline Sphaeridia cf. pumilis & 37 & 105 & 43 & 1 & 10 & 3 & 17 \\
\hline Sminthurinus sp.1 & - & - & 1 & - & - & - & - \\
\hline Collembola, all & 406 & 1096 & 884 & 1216 & 947 & 697 & 328 \\
\hline
\end{tabular}

${ }^{1}$ Total number of Collembola from 16 soil samples per orchard (sample $=4.8 \mathrm{~cm}$ diameter, $10 \mathrm{~cm}$ deep) from experimental orchards in Sooretama (SO) municipality; $\mathrm{G}=$ drip irrigation, $\mathrm{M}=$ microsprinkler irrigation.

${ }^{2}$ Total number of Collembola from 12 soil samples per orchard (sample $=4.8 \mathrm{~cm}$ diameter, $10 \mathrm{~cm}$ deep) from commercial orchards in Linhares municipality; LB, NB, CA and SV are the names of the owners of the orchards. 
Table 2. Diversity and related characteristics of collembolan communities in the soil of papaya orchard study sites managed with contrasting conventional production $(P C)$ and integrated production (PI) systems.

\begin{tabular}{|c|c|c|c|c|c|c|c|}
\hline \multirow{2}{*}{ Community characteristic } & \multicolumn{7}{|c|}{ Papaya Orchard } \\
\hline & $\mathrm{SO} \mathrm{PC}^{1}$ & SO PI-G ${ }^{1}$ & SO PI-M ${ }^{1}$ & $\mathrm{LB} \mathrm{PC}^{2}$ & NB PC ${ }^{2}$ & $\mathrm{CA} \mathrm{PI}^{2}$ & $\mathrm{SV} \mathrm{PI}^{2}$ \\
\hline Mean density (x 1000 per $\mathrm{m}^{2}$ ) & 14.0 & 37.8 & 30.5 & 56.0 & 43.6 & 32.1 & 15.1 \\
\hline No. of species (richness, $s$ ) & 10 & 16 & 17 & 15 & 16 & 8 & 12 \\
\hline Diversity, $H^{\prime}$ & 0.80 & 0.92 & 0.91 & 0.82 & 0.60 & 0.40 & 0.43 \\
\hline Equitability, $E, H^{\prime} / \ln s$ & 0.80 & 0.76 & 0.74 & 0.70 & 0.50 & 0.44 & 0.40 \\
\hline \multirow[t]{9}{*}{ Dominant species ${ }^{3}$} & & & Wbre & & & Fcub & Arl1 \\
\hline & Mama & Mama & Mama & Mama & Mama & & Mama \\
\hline & & Fony & Fony & Fony & Fony & Fony & \\
\hline & & & Fcen & & & & \\
\hline & Fpar & Fpar & Fpar & Fpar & Fpar & Fpar & \\
\hline & Pbiu & Pbiu & & & & & \\
\hline & Pse2 & Pse2 & & & Pse2 & & \\
\hline & Nmin & Nmin & Nmin & Nmin & & & \\
\hline & Spum & Spum & & & & & Spum \\
\hline$\%$ dominant $^{4}$ & 92 & 89 & 85 & 85 & 92 & 95 & 88 \\
\hline
\end{tabular}

${ }^{1}$ Collembola collected from 16 soil samples per orchard (sample $=4.8 \mathrm{~cm}$ diameter, $10 \mathrm{~cm}$ deep) from experimental orchards in Sooretama (SO) municipality; $\mathrm{G}=$ drip irrigation, $\mathrm{M}=$ microsprinkler irrigation.

${ }^{2}$ Collembola collected from 12 soil samples per orchard (sample $=4.8 \mathrm{~cm}$ diameter, $10 \mathrm{~cm}$ deep) from commercial orchards in Linhares municipality; LB, NB, CA and SV are the names of the owners of the orchards. ${ }^{3}$ Dominant species $=$ species with $5 \%$ or more of the total number of Collembola from each orchard:

Wbre, Willemia brevispina; Fcub, Fissuraphorura cubanica; Arl1, Arlea sp.1; Mama, Mesaphorura amazonica; Fony, Folsomina cf. onychiurina; Fcen, Folsomides centralis; Fpar, Folsomides parvulus; Pbiu, Pseudosinella cf. biunguiculata; Pse2, Pseudosinella sp. 2; Nmin, Neelus cf. minimus; Spum, Sphaeridia cf. pumilis.

${ }^{4} \%$ dominant, total percentage of the dominant species of the total number of Collembola from each orchard. 


\section{References}

ADIS, J. 2000. Terrestrial arthropods in soils from inundation forests and deforested floodplains of white water rivers in Central Amazonia. In The Central Amazon floodplain: actual use and options for a sustainable management (W.J Junk, J.J. Ohly, M.T.F. Piedade, \& M.G.M. Soares, eds.). Backhuys Publishers, Leiden, p. 463-476.

ADIS, J., MORAIS, J.W. DE, RIBEIRO, E.F. \& RIBEIRO, J.C. 1989. Vertical distribution and abundance of arthropods from white sand soil of a Neotropical campinarana forest during the rainy season. Stud. Neotrop. Fauna \& Environm. 24:193-200.

ANDRE, H.M., NOTI, M.I. \& LEBRUN, P. 1994. The soil fauna: the other last biotic frontier. Biodivers. Conser. 3:45-56.

ANDRÉN, O. \& LAGERLOF, J. 1980. The abundance of soil animals (Microarthropoda, Enchytraeidae, Nematoda) in a crop rotation dominated by ley and in a rotation with varied crops. In Soil biology as related to land use practices (D.L. Dindal, ed.). EPA, Washington, p.274-279.

ANDRÉN, O. \& LAGERLOF, J. 1983. Soil fauna (Microarthropods, Enchytraeids, Nematodes) in Swedish agricultural cropping systems. Acta Agric. Scand. 33:33-52.

ARLÉ, R. 1939. Quelques Collemboles de l'etat d'Espirito Santo (Bresil). Physis 17:125-131.

ARLÉ, R. 1981. Conspecto das espécies brasileiras de Pseudachorutinae, com descrição de uma espécie nova da Colômbia (Insecta, Collembola). Acta Amazonica 11:583-593.

ARTEMJEVA, T.I. \& GATILOVA, F.G. 1975. Soil mesofauna changes under the influence of various fertilizers. In Progress in soil zoology (J. Vanek, ed.). Academia, Prague, p.463-468.

AXELSEN, J.A. \& KRISTENSEN, K.T. 2000. Collembola and mites in plots fertilised with different types of green manure. Pedobiologia 44:556-566.

BADEJO, M.A. \& VAN STRAALLEN, N.M., 1993. Seasonal abundance of springtails in two contrasting environments. Biotropica 25:222-228.

BADEJO, M.A., TIAN, G. \& BRUSSAARD, L. 1995. Effect of various mulches on soil microarthropods under a maize crop. Biol. Fertil. Soils 20:294-298.

BELLINGER, P.F., CHRISTIANSEN, K.A. \& JANSSENS, F. 1996-2005. Checklist of the Collembola of the world. http:/ /www.collembola.org

BINSFELD R., SILVAL.B., ARRUDA, V.M., NICÁCIO, J. DO N., \& SANTOS, H.R. DOS. 2004. Abundância de Collembola (Arthropoda:Ellipura), em mata ciliar do Rio Miranda - Pantanal sul mato-grossense. Anais, XX Congresso Brasileiro de Entomologia, Gramado.
CHRISTIANSEN K. \& BELLINGER, P. 1998. The Collembola of North America, north of the Rio Grande: a taxonomic analysis. 2nd ed. Grinnell College, Grinnell. 4 v. p.1-1518.

CROSSLEY, D.A. JR., MUELLER, B.R., \& PERDUE, J.C. 1992. Biodiversity of microarthropods in agricultural soils: relations to processes. Agric. Ecosystems Environ. 40:37-46.

CULIK, M.P., SOUZA, J.L. DE, VENTURA, J.A. 2002. Biodiversity of Collembola in tropical agricultural environments of Espírito Santo, Brazil. Applied Soil Ecology 21:49-58.

CULIK, M.P., ZEPPELINI FILHO, D. 2003. Diversity and distribution of Collembola (Arthropoda: Hexapoda) of Brazil. Biodiversity and Conservation 12:1119-1143.

DITTMER, S. \& SCHRADER, S. 2000. Longterm effects of soil compaction and tillage on Collembola and straw decomposition in arable soil. Pedobiologia 44:527-538.

FRANKLIN E.N., MORAIS J.W., SANTOS E.M.R., 2001. Density and biomass of Acari and Collembola in primary forest, secondary regrowth and polycultures in central Amazonia. Andrias 15: 141-153.

HEISLER, C. \& KAISER, E. 1995. Influence of agricultural traffic and crop management on Collembola and microbial biomass in arable soil. Biol. Fertil. Soils 19:159-165.

HENEGHAN, L., COLEMAN, D.C., ZOU, X., CROSSLEY JR., D.A. \& HAINES, B.L. 1998. Soil microarthropod community structure and litter decomposition dynamics: A study of tropical and temperate sites. Appl. Soil Ecol. 9:33-38.

HOPKIN, S.P. 1997. Biology of the springtails (Insecta: Collembola). Oxford Univ. Press, Oxford.

HOPKIN, S.P. 2002. Collembola. In Encyclopaedia of Soil Science (R. Lal, ed.). Marcel Dekker, New York, p.207-210.

LARINK, O., 1997. Springtails and mites: important knots in the food web of soils. In Fauna in soil ecosystems: recycling processes, nutrient fluxes, and agricultural production (G. Benckiser, ed.). Marcel Dekker, New York, p.225-264.

MADGE, D.S. 1965. Leaf fall and litter disappearance in a tropical forest. Pedobiologia. 5:273-288.

MARI MUTT, J.A. \& BELLINGER, P.F. 1990. A catalog of the Neotropical Collembola, including Nearctic areas of Mexico. Sandhill Crane Press. Gainesville, Florida.

MARI MUTT, J.A. \& BELLINGER P.F. 1996. Supplement to the catalog of the Neotropical Collembola-August 1989 to April 1996. Caribbean J. of Science 32:166-175.

MARI MUTT, J.A., BELLINGER, P.F. \& JANSSENS, F. 19962001. Checklist of the Collembola: Supplement to the Catalog of the Neotropical Collembola - May 1996 to 2001. http://www.collembola.org/publicat/neotrcat.htm (ultimo acesso em 05/01/2006). 
MARTINS, D. DOS S., YAMANISHI, O.K. \& TATAGIBA, J. DA S. 2003. Normas técnicas e documentos de acompanhamento da produção integrada de mamão. Documentos, 120. Incaper, Vitória, p.1-60.

MITRA, S.K., 1993. Effects of continuous cultivations and other agronomic practices on soil microarthropods: a unifying concept of agriculture and ecology for tropical agroecosystem. Records of the Zool. Sur. of India, Occas. Paper No. 151. Zool. Survey of India, Calcutta.

MORI, S.A. 1989. Eastern, Extra-Amazonian Brazil. In Floristic inventory of tropical countries: the status of plant systematics, collections, and vegetation, plus recommendations for the future (D.G. Campbell \& H.D. Hammond, eds.). New York Botanical Garden, Bronx, New York, p.427-454.

OLIVEIRA, E.P. \& DEHARVENG, L. 1995. Response of soil Collembola (Insecta) communities to forest disturbance in central Amazonia (Brazil). In Functioning and Dynamics of Natural and Perturbed Ecosystems (D. Bellan, G. Bonin \& C. Emig, ed.). Intercept Ltd, Technique et Documentation, Lavoisier, p. 361-376.

PANKHURST, C.E., DOUBE, B. M., GUPTA, V.V.S.R. \& GRACE, P.R. (eds.). 1994. Soil biota management in sustainable farming systems. CSIRO. East Melbourne.

PETERSEN, H. \& LUXTON, M. 1982. A comparative analysis of soil fauna and their role in decomposition processes. Oikos 39:287-388.

POTAPOV, M. \& CULIK, M. 2002. A new species of Folsomia (Collembola: Isotomidae) from Brazil,with notes on foil-setae in the fimetaria group. Pan-Pacific Entomol. 78:69-73.

SALT, G. 1952. The arthropod population of the soil in some East African pastures. Bull. Entomol. Res. 43:203-220.

SIAG. 2006. Sistema de Informações Agrometeorológicas SIAG. INCAPER, Linhares.http://www.incaper.es.gov.br/ clima/index.htm (ultimo acesso em 05/01/2006).

STORK, N.E. \& EGGLETON, P. 1992. Invertebrates as indicators of soil quality. Amer. J. Altern. Agric. 7:38-47.

STRAUBE, F. 2004. Listas faunísticas: matéria-prima em extinção. Ambientebrasil, São Paulo. http:// www.ambientebrasil.com.br/composer.php3?base=./ especie/fauna/index.html\&conteudo=./especie/fauna/ artigos/extincao.html (ultimo acesso em 05/01/2006).

TATAGIBA, J. DA S., ANDRADE, J. DE S., LIMA, R. DE C.A., COUTO, A. DE O.F., VENTURA, J.A., COSTA, H., FANTON, C.J. \& MARTINS, D. DOS S. 2003. Benefícios gerados pela implantação de produção integrada de mamão quanto ao uso de agrotóxicos no norte do Espírito Santo. In Papaya Brasil: qualidade do mamão para o mercado interno (D. dos S. Martins, ed.). Incaper, Vitória, p.570-573.
THIBAUD, J.M. \& PALACIOS-VARGAS, J.G. 1999. Brazilian Collembola from littoral sand with descriptions of Austrogastrura gen. n. and Isotomodes carioca sp. n. Revue Francais d'Entomologie 21:25-31.

WINTER, J.P., VORONEY, R.P., AINSWORTH, D.A. 1990. Soil microarthropods in long-term no-tillage and conventional tillage corn production. Can. J. Soil Sci. 70:641-653.

ZEPPELINI FILHO, D. \& BELLINI, B.C. 2004. Introdução ao estudo dos Collembola. Editora da UFPB, João Pessoa.

Title: Collembola (Arthropoda: Hexapoda) Communities in the Soil of Papaya Orchards Managed with Conventional and Integrated Production in Espírito Santo, Brazil

Authors: Culik, M.P.; Martins, D.S. and Ventura, J.A.

Biota Neotropica, Vol. 6 ( number 3): 2006

http://www.biotaneotropica.org.br/v6n3/en/ abstract?short-communication+bn02006032006

Date Received 06/01/2006 - Revised 07/20/2006 Accepted 09/27/2006

ISSN 1676-0611 